An Exploratory Study of Heuristics for Anticipating Prices

\begin{tabular}{|r|l|}
\hline Journal: & Management Decision \\
\hline Manuscript ID & MD-05-2021-0619.R1 \\
\hline Manuscript Type: & Original Article \\
\hline Keywords: & Banking, Cognition, Decision making, Uncertainty, Interviews, Heuristics \\
\hline \multicolumn{2}{|l}{} \\
\hline
\end{tabular}

SCHOLARONE $^{\text {Im }}$

Manuscripts 


\section{ABSTRACT:}

This research explores how investment and central bankers cope with strategic uncertainty when they anticipate prices. The uncertainty originates from othersâ $€^{\mathrm{TM}}$ decisions and their consequences, and cannot be meaningfully reduced to risk. We postulate that, in order to cope with this type of uncertainty, bankers use simple rules, also called heuristics. This study aims to identify such heuristics and the psychological processes that underlie them.

We interviewed 22 managers of teams tasked to anticipate prices, in two leading investment and central banks. The primary data came from in-depth, semi-structured interviews lasting 30 to 60 minutes, supplemented by our observations during the on-site visits, emails and phone calls when preparing the interviews, and reports published by the banks. Data was coded and heuristics were induced over multiple rounds by multiple researchers.

Bankers (1) construct simple game representations of markets, (2) make inferences to gauge opponents, (3) become alert when they see too much agreement, and (4) communicate coherent narratives. Heuristics (1)â€" (3) are employed when the pace of decision making is fast, whereas (4) is used for longer time scales. In sum, bankers exhibit reciprocal bounded rationality, wherein interaction partners are mutually aware of and adapted to the fundamental uncertainty of the task and their limited resources.

CUST_RESEARCH_LIMITATIONS/IMPLICATIONS_(LIMIT_100_WORDS) :No data available.

CUST_PRACTICAL_IMPLICATIONS_(LIMIT_100_WORDS) :No data available.

CUST_SOCIAL_IMPLICATIONS_(LIMIT_100_WORDS) :No data available.

Heuristics for anticipating prices have not been studied empirically outside the lab. The findings may help integrate conceptualizations of heuristics in the simple-rules and fast-and-frugal-heuristics research programs, and improve market efficiency. 


\title{
An Exploratory Study of Heuristics for Anticipating Prices
}

\begin{abstract}
Purpose. This research explores how investment and central bankers cope with strategic uncertainty when they anticipate prices. The uncertainty originates from others' decisions and their consequences, and cannot be meaningfully reduced to risk. We postulate that, in order to cope with this type of uncertainty, bankers use simple rules, also called heuristics. This study aims to identify such heuristics and the psychological processes that underlie them.

Design/methodology/approach. We interviewed 22 managers of teams tasked to anticipate prices, in two leading investment and central banks. The primary data came from indepth, semi-structured interviews lasting 30 to 60 minutes, supplemented by our observations during the on-site visits, emails and phone calls when preparing the interviews, and reports published by the banks. Data was coded and heuristics were induced over multiple rounds by multiple researchers.

Findings. Bankers (1) construct simple game representations of markets, (2) make inferences to gauge opponents, (3) become alert when they see too much agreement, and (4) communicate coherent narratives. Heuristics (1)-(3) are employed when the pace of decision making is fast, whereas (4) is used for longer time scales. In sum, bankers exhibit reciprocal bounded rationality, wherein interaction partners are mutually aware of and adapted to the fundamental uncertainty of the task and their limited resources.
\end{abstract}

Originality. Heuristics for anticipating prices have not been studied empirically outside the lab. The findings may help integrate conceptualizations of heuristics in the simple-rules and fast-and-frugal-heuristics research programs, and improve market efficiency.

KEYWORDS: banking, cognition, decision making, heuristics, interviews, uncertainty. 


\section{INTRODUCTION}

Price anticipation is a highly relevant but little understood area of organizational and strategic decision making (Cyert and March, 1963; Willman et al, 2006). For investment banks, the capability to anticipate prices is important for successfully launching IPOs, or building relations with pension and hedge funds. Central banks, unless they anticipate prices, cannot devise a monetary policy to control indicators such as inflation, economic growth, and unemployment.

In order to anticipate prices, market participants need to make inferences about the behavior of others. Some market participants directly affect prices, because they are large as big hedge funds are, or important as central banks are (Hong, Scheinkman, and Xiong, 2006).

Additionally, one may be aware that other agents can directly affect prices but without exactly knowing who these agents are. In short, market participants need to cope with fundamental strategic uncertainty, that is, uncertainty about others, their decisions_and the consequences thereof, as well as the same uncertainty of these other participants. Such uncertainty cannot be meaningfully reduced to risk because the probabilities of the possible outcomes are unknown or unknowable (Knight, 1921), and some outcomes per se are unknown or unknowable.

Strategic uncertainty can lead to intractable calculations. Under strategic uncertainty (Beunza and Garud, 2007; Menon 2018; Porac and Thomas, 1990; Simon, 1993), one cannot straightforwardly know how available information maps to equilibrium prices (Muth, 1961; Hong, Scheinkman, Xiong, 2006). But one can manage such uncertainty and adapt to it. Market participants may realize that they are mutually boundedly rational, that is, that they have access to limited information and time, have to deal with uncertainty as opposed to risk, and that others are on the same boat; and use this realization to achieve their goals. In general, simple rules, also called beuristics, have been proposed as effective means for coping with uncertainty (Bettis, 2017; Bingham and Eisenhardt, 2014; Day and Lord, 1992; Gigerenzer, Hertwig, and Pachur, 2011; Guercini and Milanesi, 2020; Katsikopoulos et al, 2020; Maitland and Sammartino, 2015). To the 
best of our knowledge, however, heuristics for anticipating prices have not been studied empirically outside the lab. This is the topic of the article.

We present an exploratory study of heuristics for anticipating prices. We induced heuristics by interviewing managers of teams tasked to anticipate prices in two leading investment and central banks. A focus was on identifying the psychological processes that underlie behavior. The identification of heuristic processes is a key part of the endeavor of understanding and improving real-world decision making (Ehrig and Schmidt, 2019; Gigerenzer and Gaissmaier, 2011; Katsikopoulos, 2022). We discuss how the findings may help to integrate conceptualizations of heuristics in the research programs of simple rules (Davis, Eisenhardt, and Bingham, 2009; Bingham and Eisenhardt, 2014), and fast-and-frugal heuristics (Gigerenzer, Hertwig, and Pachur, 2011; Katsikopoulos et al, 2020), and to improve the efficiency of the financial market.

\section{STUDY}

\section{Method}

A first set of interviews was held in an investment bank. This investment bank is part of a leading global financial services company providing services such as investment banking, private banking, and asset management, with total assets of more than 1 trillion USD. We interviewed 14 employees over two consecutive days. Most interviewees were team leaders, and five were managing directors. For instance, we interviewed the head of foreign exchange trading who trades currencies and currency options, and the head of interest rate strategy who forecasts interest rates for clients such as hedge or pension funds. Most of our interviewees were managing teams that needed to anticipate prices in the context of fixed-income products, or to create funding for complex trading strategies of institutions such as hedge funds. Ten out of the 14 investment bankers worked with fixed-income securities and four worked in equity markets.

We additionally conducted eight interviews at a major central bank. This central bank aims at delivering financial stability and monetary policy, and holds reserves of more than 600 billion USD. This set of interviews was suggested to us by two investment bankers, who said that central banks are a crucial part of the strategic environment of investment banks, for example by setting 
interest rates and monitoring compliance with financial regulation. One interviewee was a member of the bank's monetary policy committee, two were managers of large policy-development teams, and five were research staff.

The primary data source consisted of in-depth, semi-structured interviews lasting 30 to 60 minutes, performed by two of the authors. Other data sources included these authors' observations during the on-site visits, emails and phone calls when preparing the interviews, and archival data such as reports published by the banks. During the interview sessions, one author went through a list of questions, adapting them or even substituting questions according to the flow of the interview, while another author took notes. To demonstrate our intent to respect our confidentiality agreement with the banks and interviewees, we did not record any of the interviews.

We initiated the interviews by asking questions on modeling. Economic models for predicting prices are often contradicted by reality (King and Kay, 2020), and we asked how bankers deal with this issue. We also asked how they anticipate the behavior of other market participants. In particular, we asked bankers about the relevance of others to price developments, and about the fact that they do not know the reactions of others to their own actions. We asked about additional topics as well, and sample questions are provided in Table I. We asked the same set of opening questions at both banks.

\section{Insert Table I}

The data were evaluated in multiple rounds, drawing upon our research backgrounds in management, psychology, mathematics, and complex systems. More specifically, shortly after the interviews, the two authors who conducted them worked independently and then jointly on analyzing the interview notes. These two authors identified a preliminary set of strategies for coping with strategic uncertainty strategies. The author team then discussed which of these coping strategies could be viewed as "heuristics" and which of those heuristics should be analysed further. For the purposes of this study, we defined heuristics as simple rules used to reason or make decisions, or to facilitate processes supporting reasoning and decision making. 
Our analysis differs from that of Bingham and Eisenhardt (2011), who focused on the question of how heuristics are learned from experience, as well as that of Maitland and Sammartino (2015), who interviewed managers who referred to a shared timeline of events. We did not focus on idiosyncratic heuristics that were outcomes of learning processes (Bingham and Eisenhardt, 2011), nor did we code different heuristic responses to the same events (Maitland and Sammartino, 2015). Our focus was on finding cognitive tools that differed from "rational" tools such as equilibrium or statistical models, or interacted with such tools in novel or interesting ways.

These two authors identified a preliminary set of heuristics by coding patterns in the data. All authors jointly reviewed the coded data, identified further patterns, compared those with what is known in the literature, and thus arrived at a refined coding theme. Two authors then reevaluated the refined coding scheme. This whole process was repeated several times. Throughout the work, several heuristics were eliminated as already known from other contexts, and the remaining ones were successively reformulated and abstracted until four heuristics were finally identified. The final data-coding and heuristic-identification stages were subject to independent checks by a research assistant.

\section{Findings}

The findings are summarized in Table II. If an utterance of an interviewee indicates that $\mathrm{s} / \mathrm{he}$ uses a heuristic listed in the left column of Table II, the job title of the interviewee is listed in the right column of Table II, in the row associated with the heuristic. We do not indicate how often a heuristic was mentioned by an interviewee because this seemed to have been impacted by conversational style and not necessarily carry information. We provide representative quotes to illustrate the four heuristics in Tables III (construct a game), IV (gange your opponent), V (if everyone agrees, be skeptical), and VI (communicate a coherent narrative).

Insert Table II

Heuristic 1: Construct a game 
Out of the possibly thousands of market participants and all their possible actions that may influence prices, our interviewees suggested that they try to identify a few relevant players and their most likely actions. Investment bankers constructed cognitive representations of simple games, as illustrated by the following quotes (Table III): "You want to think about each of the big players separately (there are just a few of them), such as Black Water and Howard [big hedge funds]" and 'There are 30-40 big accounts that can make a difference".

Investment bankers seem to construct from scratch some elements that standard game theory takes as given, such as the sets of players and actions. Consistent with Levinthal (2011), construct a game results in coarse-grained representations of a complex and opaque interaction reality. It is hard to know if and when such simple representations are successful. The next heuristics shed some light in how bankers process these representations.

\section{Insert Table III}

\section{Heuristic 2: Gauge your opponent}

In financial theory (Ben-Porath and Heifetz, 2011), uncertainty about the beliefs and actions of other market participants implies the intractability of price anticipation even for relatively straightforward interactions (Bettis, 2017). Thus, in reality, bankers should be using intelligent shortcuts when anticipating others, accounting for the fact that they themselves as well as others could be anticipated by yet others. Thus, instead of aiming at optimizing a model, bankers should aim at doing better than others. Indeed, one central banker stated: "Players want to be epsilonbetter than others (so that they can get a bonus); they do not follow the whole infinite regress" (Table IV).

Satisficing in strategic interactions is known in the form of "level-k reasoning" in lab experiments (Hirota and Sunder, 2016; Nagel, 1995; Levine, Bernard, and Nagel, 2017). Our data outside the lab go beyond such findings. Bankers are concerned not only with the depth of reasoning, but also with the breadth of reasoning. For instance, one investment banker stated (Table IV): "I try to find out about others' relative experience and sophistication by asking them 
questions about their background, try to find out their breadth of thinking". This is an intelligent twist to just thinking at one level higher. In real markets, deep reasoning may not bring success in a strategic interaction if it is narrow and leaves out key scenarios.

Gange your opponent demonstrates reciprocal bounded rationality. If a market participant can find others who are less sophisticated than themselves, they will exploit them. And this also means that those who cannot exploit anyone else must conclude that they are being exploited by others who are more sophisticated than themselves. As two investment bankers put it, "If you can't find the sucker at the poker table, it's you" (Table IV), and "I assume that sometimes I am at a disadvantage (in terms of relative sophistication)". The data also hints at the processes by which opponents are gauged. A team leader responsible for short-term arbitrage trading reported using "a lot of tricks" to do so, for example, "putting a lot of small orders and then canceling them." These results resonate with Willman et al's (2006) finding that bankers often trade to first learn rather than to profit directly. Finally, gange your opponent is used at both banks. This makes sense because investment and central banks are players in the same financial game. A manager at the central bank stated: "Both the [investment] banks and we try to develop a theory of mind of others", and he said that he infers how others will react by using prior experience with them, by asking her/himself "how will this guy react?" and "what is he looking for?".

\section{Insert Table IV}

\section{Heuristic 3: If everyone agrees, be skeptical}

When analyzing our data, we identified a heuristic that surprised us. We called it if everyone agrees, be skeptical. What does that mean? A director in trading inflation derivatives said: "Seventy-five percent of the time, 10 of 12 dealers would agree, but they are proved wrong" (Table V).

Indeed, collective agreement can be the result of defensive decision making, that is, choosing inferior decisions that nevertheless appear accountable and can thus protect decision makers if something goes wrong (Gigerenzer, 2014). In this case, it may be wise to avoid false consensus and its negative effects as when no one wants to be the first to sell their toxic stocks and all go on 
dancing as long as the music plays. The flip side of this is that risks, if one's assessment of them is superior to the competitors' assessment, can be turned into opportunities. Thus, the heuristic if everyone agrees, be skeptical serves to spot and exploit opportunities. One investment banker said: "Howard's [the leader of a major hedge fund] strategy was to figure out what everybody else is doing and then do the opposite." And another investment banker argued: “Once everybody's moved to one side (made a bet in one direction), they are much more exposed to shocks in one direction; this is sentiments in positioning (the balance of bets is skewed)" (Table V).

The use of if everyone agrees, be skeptical indicates that investment bankers do not follow the logic of no-trade theorems, where rational agents with identical information and a priori beliefs cannot ever disagree (Aumann, 1976; Milgrom and Stokey, 1982). The irrelevance of overmathematized modeling is not news to practitioners, as Mervyn King, former governor of the Bank of England, and economist John Kay have documented (King and Kay, 2020). In fact, King and Kay suggest that financial and banking practitioners rely on rich but mostly verbal narratives. This is what we also found in the last heuristic presented below.

\section{Insert Table $\mathrm{V}$}

\section{Heuristic 4: Communicate a coherent narrative}

The modal heuristic for central bankers working in monetary policy-but not for those working in regulation-was to communicate narratives coherently. It is exemplified by the following quotes: "The $[\ldots]$ story was that the significant slack in labor market should put pay pressure down and this should lead to low inflation" (Table VI) and "[Monetary policy] committee members prefer narratives [over mathematical prediction models], even at the cost of worse predictions".

Narratives can be a device for simplifying situations in the face of strategic uncertainty; stories can contain characters such as households, banks, and so on. The narratives our interviewees mentioned often used such characters as causal actors. The causal actors are not treated as agents that think about other agents or act on them, however, but simply as causal forces. In this sense, heuristic (4) differs from heuristics (1) to (3). 
We also found that, in contrast to construct a game, gange your opponent, and if everyone agrees, be sceptical, communicate narratives coherently was used solely for slow decision-making processes with a horizon of months or longer. This is the case for the monetary policy division of the central bank. This finding contradicts a conjecture made by Vuori and Vuori (2014) that the role of heuristics might be restricted to fast-paced decisions. On the other hand, investment bankers can make decisions in weeks or days, even minutes. As such, communicate narratives coherently was used less by investment bankers, although it was still used (Table VI). The investment bankers who typically anticipate prices within short time horizons spend more time thinking strategically about the actions of others, compared to thinking about the fundamentals of assets and constructing narratives about these fundamentals.

\section{Insert Table VI}

\section{DISCUSSION}

Two research programs have highlighted the positive role of heuristics in management (Guercini and Milanesi, 2020)— the simple-rules program (Davis, Eisenhardt, and Bingham, 2009; Bingham and Eisenhardt, 2014), and the fast-and-frugal-heuristics program (Gigerenzer et al, 2011; Gigerenzer and Gaissmaier, 2011). The simple-rules program has studied heuristics that are idiosyncratic to firms, in the contexts of acquisition, internationalization, alliances, and product innovation (Brown and Eisenhardt 1997; Bingham and Eisenhardt, 2011). Brown and Eisenhardt (1997) and Davis, Eisenhardt, and Bingham (2009) argue that simple rules work well because they provide not too little, not too much structure, thus giving direction while also leaving freedom to improvise. The fast-and-frugal-heuristics program has studied the general psychological capacities that enable people — experts as well as laypeople — to make accurate and also transparent decisions, forecasts, and classifications in management and banking, and other domains (Aikman et al, 2021; Gigerenzer et al, 2011; Katsikopoulos et al, 2020; Katsikopoulos, Durbach, and Stewart, 2018). The theory of ecological rationality delineates formal conditions under which simple, sometimes 
parameter-free fast and frugal heuristics can outperform complex parameterized models, such as low variance in the predictions of heuristics (Gigerenzer and Brighton, 2009) or the existence of dominating options or cues (Katsikopoulos, 2011).

From a theory standpoint, it is critical to conceptually integrate these two research programs and the explanations they offer for heuristic success. Such efforts to date (Vuori and Vuori, 2014; Bettis, 2017, ) do not refer to tasks of strategic uncertainty. Our empirical findings may help build a theory of ecological rationality in the presence of strategic uncertainty in a number of ways, and we outline two below.

First, for some particular heuristics, we uncovered dominating cues. For example, gange your opponent can be successful if it employs the breadth-of-reasoning cue, and if everyone agrees, be skeptical is a single-cue heuristic. Here, a challenge in integration is that simple rules, unlike fast and frugal heuristics, are typically not presented as cue-based but directly as rules for action as in "restrict internationalization to Asia" or "target large enterprises" (Bingham and Eisenhardt, 2011, Table 2). Perhaps, however, such simple rules are also supported by cues, and a topic for future research would be to make those cues explicit. Second, in a more general sense, the game representations and financial narratives constructed by our participants can be related to the concept of not too little/not too much structure. These representations and narratives have some structure but are neither formal nor rigid. An interesting question for further integrative research here is how such structures are learned and developed, either by individual managers or by organizations. The simple-rules program has studied this question (Bingham and Eisenhardt, 2011), but less is known with regards to fast and frugal heuristics despite the fact that such knowledge is key for understanding how managers come up with bundles of effective heuristics (Cavaretta, 2021).

With regards to practice, our data suggest that bankers, when anticipating prices, are not concerned with efficiency in ways similar to those in neoclassical and behavioral economics and finance. Rather, bankers seem to be aware that markets are, at least in the short run, characterized by disequilibrium dynamics (Roberts and Eisenhardt, 2003). Disequilibrium dynamics imply that 
mispricing may prevail and thus, markets may be inefficient in the short run. On the other hand, the heuristics of reciprocal bounded rationality, such as if everybody agrees, be skeptical allow bankers to spot and exploit inefficiencies.

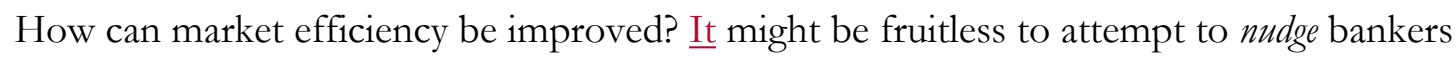
towards being more efficient, without first understanding how they think and what their goals are. This is a known critique in situations of known risks (Reijula et al, 2018; Sugden, 2009), and it applies at least as much in situations of uncertainty, and possibly even more of strategic uncertainty. Nudging trading teams to "slow" thinking and "rational" deliberation might miss the point, if regulators, traders, investment and central bankers do not mutually understand the heuristics each of them use. Boost (Hertwig and Grüne-Yanoff, 2017) is an alternative to nudge that aims at empowering decision makers by providing knowledge and enhancing competencies. In the context of financial markets, boost interventions should go beyond the standard education in economics and finance that focuses on coping with risk, and empower policymakers and bankers to cope with uncertainty (Katsikopoulos et al, 2020). There are, however, gaps in the empirical evidence on the comparative efficacy of nudge and boost (van Roekel, Reinhard, and Grimmelikhuijsen, 2021), including the anticipation of prices. This is a task for the future. 


\section{REFERENCES}

Aikman, D., Galesic, M., Gigerenzer, G., Kapadia, S., ... and Neumann, T. (2021). Taking uncertainty seriously: simplicity versus complexity in financial regulation. Industrial and Corporate Change.

Aumann R. J. (1976). Agreeing to disagree. Annals of Statistics, 4: 1236-1239.

Ben-Porath, E., and Heifetz, A. (2011). Common knowledge of rationality and market clearing in economies with asymmetric information. Joumal of Economic Theory, 146(6), 2608-2626.

Bettis, R. A., (2017). Organizationally intractable decision problems and the intellectual virtues of heuristics. Journal of Management, 43(8), pp.2620-2637.

Beunza, D., and Garud, R. (2007). Calculators, lemmings or frame-makers? The intermediary role of securities analysts. The Sociological Review, 55(2_suppl), 13-39.

Bingham C. B., and Eisenhardt KM. (2011). Rational heuristics: the 'simple rules' that strategists learn from process experience. Strategic Management Journal 32: 1437-1464.

Brown S. L., and Eisenhardt K. M. (1997). The art of continuous change: linking complexity theory and time-paced evolution in relentlessly shifting organizations. Administrative Science Quarterly 42(1): 1-34.

Cavarretta, F. L. (2021). On the hard problem of selecting bundles of rules: a conceptual exploration of heuristic emergence processes. Management Decision.

Cyert, R. M., and March, J. G. (1963). A Behavioral Theory of the Firm. Routledge: London, UK.

Davis, J. P., Eisenhardt, K. M., and Bingham, C. B. (2009). Optimal structure, market dynamism, and the strategy of simple rules. Administrative Science Quarterly, 54(3), 413-452.

Day, D. V., and Lord, R. G. (1992). Expertise and problem categorization: the role of expert processing in organizational sense-making. Journal of Management Studies, 29(1), 35-47.

Ehrig, T., and Schmidt, J. (2019). Making biased but better predictions: The trade-offs strategists face when they learn and use heuristics. Strategic Organization, 1476127019869646.

Gigerenzer, G. (2014). Risk Savry: How to Make Good Decisions. Penguin: London, UK.

Gigerenzer, G., and Brighton H. (2009). Homo Heuristicus: why biased minds make better inferences. Topics in Cognitive Science 1: 107-143.

Gigerenzer, G., and Gaissmaier, W. (2011). Heuristic decision making. Annual Review of Psychology 62: 451-482.

Gigerenzer, G., Hertwig, R., and Pachur, T. (eds). (2011). Heuristics: The Foundations of Adaptive Behavior. Oxford University Press: New York.

Gigerenzer G., and Selten R. (eds). (2001). Bounded Rationality: The Adaptive Toolbox. MIT Press: Cambridge, MA.

Guercini, S., and Milanesi, M. (2020). Heuristics in international business: A systematic literature review and directions for future research. Journal of International Management, 26(4), 100782.

Hertwig, R., and Grüne-Yanoff, T. (2017). Nudging and boosting: Steering or empowering good decisions. Perspectives on Psychological Science, 12(6), 973-986.

Hirota, S., and Sunder, S. (2016). Price bubbles sans dividend anchors: Evidence from laboratory stock markets. In Behavioral Interactions, Markets, and Economic Dynamics (pp. 357-395).

Hong, H., Scheinkman, J., and Xiong, W. (2006). Asset float and speculative bubbles. The Journal of Finance, 61(3), 1073-1117.

Katsikopoulos, K. V. (2011). Psychological heuristics for making inferences: definition, performance, and the emerging theory and practice. Decision Analysis 8(1): 10-29.

Katsikopoulos, K. V. (2022). Cognitive Operations: Modeling Psychological Processes and Predicting Decisions. Palgrave Macmillan: London, UK.

Katsikopoulos, K. V., Durbach, I. N., and Stewart, T. J. (2018). When should we use simple decision models? A synthesis of various research strands. Omega 81: 17-25.

Katsikopoulos, K. V., Şimşek, O., Buckmann, M., and Gigerenzer, G. (2020). Classification in the Wild: The Science and Art of Transparent Decision Making. MIT Press: Cambridge, MA. 
King, M., and Kay, J. (2020). Radical Uncertainty: Decision-Making for an Unknowable Future. Hachette: London, UK.

Knight F. H. (1921). Risk, Uncertainty, and Profit. Houghton Mifflin: Boston, MA.

Levine S. S., Bernard M., and Nagel R. C. (2017). Know thyself, know thy rival: experimental evidence on how strategic IQ benefits performance. In Academy of Management Proceedings (Vol. 2015, No. 1, p. 11121). Academy of Management: Briarcliff Manor, NY.

Levinthal D. A. (2011). A behavioral approach to strategy — what's the alternative? Strategic Management Journal 32(13): 1517-1523.

Maitland E., and Sammartino A. (2015). Decision making and uncertainty: the role of heuristics and experience in assessing a politically hazardous environment. Strategic Management Journal, 36(10): 1554-1578.

Menon, A. (2018). Bringing cognition into strategic interactions: Strategic mental models and open questions. Strategic Management Journal, 39(1), 168-192.

Milgrom P., and Stokey N. (1982). Information trade and common knowledge, Journal of Economic Theory 26: 17-27.

Muth, J. F. (1961). Rational expectations and the theory of price movements. Econometrica, 315-335.

Nagel, R. (1995). Unraveling in guessing games: An experimental study. The American Economic Review, 85(5), 1313-1326.

Porac J. F., and Thomas, H. (1990). Taxonomic mental models in competitor definition. Academy of Management Review 15(2): 224-240.

Reijula, S., Kuorikoski, J., Ehrig, T., Katsikopoulos, K., and Sunder, S. (2018). Nudge, boost, or design? Limitations of behaviorally informed policy under social interaction, Journal of Behavioral Economics for Policy, Special Issue on Nudges and Heuristics, 2(1): 99-105.

Roberts, P. W. and Eisenhardt, K. M., 2003. Austrian insights on strategic organization: from market insights to implications for firms.

Simon H. A. (1993). Strategy and organizational evolution. Strategic Management Journal, Winter Special Issue: Organizations, Decision Making and Strategy 14: 131-142.

Sugden, R. (2009). "On nudging: A review of nudge: Improving decisions about health, wealth and happiness by Richard H. Thaler and Cass R. Sunstein.", International Journal on the Economics of Business, 16(3): 365-373.

Sull, D., and Eisenhardt, K. M. (2015). Simple Rules: How to Thrive in a Complex World. Houghton Mifflin: Boston, MA.

Van Roekel, H., Reinhard, J., and Grimmelikhuijsen, S. (2021). Improving hand hygiene in hospitals: comparing the effect of a nudge and a boost on protocol compliance. Behavioural Public Policy, 1-23.

Vuori N., and Vuori T. (2014). Comment on "Heuristics in the strategy context" by Bingham and Eisenhardt (2011). Strategic Management Journal 35(11): 1689-1697.

Willman, P., Fenton-O'Creevy, M., Nicholson, N., and Soane, E. (2006). Noise trading and the management of operational risk; firms, traders and irrationality in financial markets. Journal of Management Studies, 43(6), 1357-1374. 
Table I. A sample of the opening questions used in the interviews

\begin{tabular}{|c|c|}
\hline Topic & Sample questions \\
\hline \multirow[t]{2}{*}{ Revising theories to predict markets } & $\begin{array}{l}\text { What parts of a theory do you keep under all conditions and what } \\
\text { parts are you willing to give up, and when? }\end{array}$ \\
\hline & $\begin{array}{l}\text { How do you recognize a structural change in a process and } \\
\text { distinguish it from a short-term, random fluctuation? }\end{array}$ \\
\hline \multirow[t]{2}{*}{$\begin{array}{l}\text { Building consensus about an economic } \\
\text { development }\end{array}$} & $\begin{array}{l}\text { How are contradictory explanations or forecasts of an economic } \\
\text { phenomenon dealt with? }\end{array}$ \\
\hline & How are the outputs of different mathematical models combined? \\
\hline \multirow[t]{2}{*}{$\begin{array}{l}\text { Extracting information about other players } \\
\text { from prices }\end{array}$} & What information about other players do you extract from prices? \\
\hline & What other information can you extract from prices? \\
\hline \multirow[t]{2}{*}{$\begin{array}{l}\text { Figuring out other players in the market and } \\
\text { their actions }\end{array}$} & How do you determine the players in a market? \\
\hline & $\begin{array}{l}\text { How do you determine the relative sophistication, in terms of } \\
\text { reasoning, of other players? }\end{array}$ \\
\hline
\end{tabular}


Table II. Definitions of heuristics and their usage

\begin{tabular}{|c|c|c|}
\hline Heuristic & Definition & User \\
\hline $\begin{array}{l}\text { Construct a } \\
\text { game }\end{array}$ & $\begin{array}{l}\text { Rules that lead to a simplified } \\
\text { representation of a macroscopic } \\
\text { or microscopic market } \\
\text { interaction, using elements of } \\
\text { "games" as in game theory. }\end{array}$ & $\begin{array}{l}\text { Investment bank: Head of debt capital markets; Interest rate } \\
\text { strategist; Salesman for high yield bonds; Director in trading } \\
\text { inflation derivatives; Deputy chief trust officer. }\end{array}$ \\
\hline $\begin{array}{l}\text { Gange your } \\
\text { opponent }\end{array}$ & $\begin{array}{l}\text { Rules for inferring other players' } \\
\text { relative sophistication compared } \\
\text { to one's own, in terms of depth } \\
\text { and breadth of reasoning. }\end{array}$ & $\begin{array}{l}\text { Investment bank: Head of debt capital markets; Senior fixed } \\
\text { income options trader; Interest rate strategist; Senior trader in } \\
\text { equities; Director in trading inflation derivatives; Money } \\
\text { market trader; Director in equity research sales; Head of } \\
\text { interest rate strategy; Director in foreign exchange sales. } \\
\text { Central bank: Senior manager in the macroprudential } \\
\text { division; Manager in the macroprudential division; Manager in } \\
\text { the market sectors and interlinkages division. }\end{array}$ \\
\hline $\begin{array}{l}\text { If everyone } \\
\text { agrees, be } \\
\text { skeptical }\end{array}$ & $\begin{array}{l}\text { Decision rule that exploits the } \\
\text { indicative value of too much } \\
\text { agreement, in order to avoid risks } \\
\text { and exploit opportunities in } \\
\text { markets. }\end{array}$ & $\begin{array}{l}\text { Investment bank: Director in trading inflation derivatives; } \\
\text { Trader; Head of interest rate strategy; Equity research analyst. }\end{array}$ \\
\hline $\begin{array}{l}\text { Communicate } \\
\text { a coherent } \\
\text { narrative }\end{array}$ & $\begin{array}{l}\text { Communication rule stating that } \\
\text { price-related events and } \\
\text { developments should be put } \\
\text { together in a story, featuring } \\
\text { characters and causal forces. }\end{array}$ & $\begin{array}{l}\text { Investment Bank: Head of debt capital markets; Equity } \\
\text { research analyst. } \\
\text { Central Bank: Senior economist in the structural economic } \\
\text { analysis division; Senior manager in the conjectural assessment } \\
\text { and projections division; Member of the monetary policy } \\
\text { committee; Economist in the monetary analysis and statistics } \\
\text { division. }\end{array}$ \\
\hline
\end{tabular}


Table III. Representative quotes for heuristic 1: Construct a game

\section{Quote}

1. "You want to think about each of the big players separately (there are just a few of them), such as Black Water and Howard [big hedge funds]."

2. "I think about key players in
the market; there are $30-40$ big
accounts that can make a
difference."

3. "To find out who the key players are, I read and interview."

\section{Job of the interviewee, context of the quote, and mapping to definition} of heuristic
Investment banker who worked in the aggregate risk management division of the investment bank, and had previously traded for a hedge fund. This banker made clear distinctions about what to include and exclude in this simplified representation ("there are just a few of them") and s/he is also clear about what not to group into a category ("think about each ... separately").
Managing director at the investment bank who buys and sells high yield bonds (bonds of low credit quality). A simplified representation was created by becoming aware of who "makes a difference". As in the row above, the manager seems to believe in her/his ability to simplify a complex market by thinking about "big" players, thereby transforming a macroscopic interaction with many players to a simple "game."

\section{Head of debt capital markets at the investment bank, who had} 25 years experience and dealt mainly with IPOs of company bonds. Investment banks have a vested interest in IPOs running successfully, upon which their consultancy charges depend, so they also have an interest in understanding the key players who may sign company bonds. The interviewee searches for a simplified representation of the players involved in an IPO.

\begin{tabular}{ll}
\hline 4. "I ask myself what other & $\begin{array}{l}\text { Interest rate strategist at the investment bank, who writes reports and talks to } \\
\text { players finally price. I cannot }\end{array}$ \\
clients about the investment bank's views on where interest rates are going. \\
$\begin{array}{ll}\text { I know all of the other players, but } \\
\text { The quote implies constructing a game, where the strategist does not think }\end{array}$ \\
$\begin{array}{l}\text { about all players but instead about the "important" ones and their likely } \\
\text { actions ("what will they finally price?"). }\end{array}$
\end{tabular}


Table IV. Representative quotes for heuristic 2: Gauge your opponent

\begin{tabular}{|l|l|}
\hline Quote & $\begin{array}{l}\text { Job of the interviewee, context of the quote, and mapping to } \\
\text { definition of heuristic }\end{array}$ \\
\hline $\begin{array}{l}\text { 1. 'I try to find out about others' relative } \\
\text { experience and sophistication by asking } \\
\text { them questions about their background, } \\
\text { try to find out their breadth of thinking." }\end{array}$ & $\begin{array}{l}\text { Head of debt capital markets in the investment bank, who had } \\
\begin{array}{l}\text { The manager attempts to infer both the breadth and depth of } \\
\text { opponents' thinking to predict their behavior. }\end{array}\end{array}$ \\
\hline $\begin{array}{l}\text { 2. "If you can't find the sucker on the } \\
\text { poker table, it's you." }\end{array}$ & $\begin{array}{l}\text { Senior fixed income options trader in the investment bank, with 25- } \\
\text { 30 years of experience, who here draws an analogy between options } \\
\text { trading and poker. The quote implies a belief in a hierarchy of skill. } \\
\text { Option trading is seen here as a zero-sum game where the existence } \\
\text { of winners implies the existence of losers. }\end{array}$ \\
\hline $\begin{array}{l}\text { 3. "Players want to be epsilon-better than } \\
\text { others (so that they can get a bonus), they } \\
\text { do not follow the whole infinite regress [of } \\
\text { reasoning about reasoning of others]." }\end{array}$ & $\begin{array}{l}\text { Senior manager in the macroprudential division of the central bank. } \\
\text { The quote refers to thinking about the thinking of investment } \\
\text { bankers when they respond to regulation rules. }\end{array}$ \\
\hline $\begin{array}{l}\text { 4. "I am interested in determining the } \\
\text { relative sophistication of players; in this, I } \\
\text { have a competitive advantage because I } \\
\text { have worked in [the capita marketl]; can } \\
\text { correct misconceptions both ways } \\
\text { [between clients and policy makers]." }\end{array}$ & $\begin{array}{l}\text { Interest rate strategist in the investment bank. The strategist is } \\
\text { particularly knowledgeable about politics and credit markets and } \\
\text { considers constraints both of the investment bank's clients (e.g., } \\
\text { institutional funds trading through the investment bank) and policy } \\
\text { makers. Awareness of both perspectives makes it possible to infer } \\
\text { when the strategist has an edge (e.g., when the perspectives mismatch } \\
\text { and can be corrected). }\end{array}$ \\
\hline
\end{tabular}


Table V. Representative quotes for heuristic 3: If everyone agrees, be skeptical

\begin{tabular}{|c|c|}
\hline Quote & $\begin{array}{l}\text { Job of the interviewee, context of the quote, and mapping to } \\
\text { definition of heuristic }\end{array}$ \\
\hline $\begin{array}{l}\text { 1. "Seventy-five percent of the time, } 10 \text { of } \\
12 \text { dealers would agree, but they are } \\
\text { proved wrong." }\end{array}$ & $\begin{array}{l}\text { Director at the investment bank who makes markets for inflation } \\
\text { products. The utterance implies alertness, in particular when } \\
\text { competing trading parties in the market for inflation products agree } \\
\text { in their viewpoints. The banker seems to assume that in the short } \\
\text { run, markets are not information efficient but fluctuate as the traders } \\
\text { form herds and adopt each other's viewpoints. }\end{array}$ \\
\hline $\begin{array}{l}\text { 2. "Once everybody's moved to one side } \\
\text { (made a bet in one direction) they are } \\
\text { much more exposed to shocks in one } \\
\text { direction; this is sentiments in positioning } \\
\text { (the balance of bets is skewed)." }\end{array}$ & $\begin{array}{l}\text { Head of interest rate strategy at the investment bank, who runs a } \\
\text { team of } 6 \text { people on interest rate strategy, conducts research, makes } \\
\text { forecasts, and also meets investors. As in the row above, the manager } \\
\text { is alert when perceiving too much agreement in the market. In } \\
\text { addition, an explanation is provided of why too much agreement in } \\
\text { the marketplace is an indicator of risk. }\end{array}$ \\
\hline $\begin{array}{l}\text { 3. "If you have too much agreement, then } \\
\text { it could very easily go the other way." }\end{array}$ & $\begin{array}{l}\text { Equity research analyst who writes equity research reports for the } \\
\text { investment bank. The quote refers to herding of viewpoints among } \\
\text { analysts. Although the collective agreement among equity research } \\
\text { analysts may be a result of defensive decision making (single analysts } \\
\text { do not want to deviate from the collective viewpoint in order to } \\
\text { protect themselves if something goes wrong), the analyst is aware that } \\
\text { collective agreement also points to a risk. }\end{array}$ \\
\hline 4. "The market is almost always wrong." & $\begin{array}{l}\text { Trader in the investment bank. Like the market maker for inflation } \\
\text { products (see quote (1)), the trader seems to assume that in the short } \\
\text { run, markets are not information efficient but fluctuate as the traders } \\
\text { form herds and adopt each other's viewpoints. This trader responded } \\
\text { to this condition by specializing in risk management: "I only need to } \\
\text { be right } 40 \% \text { of the time and let winners run and cut losers short, and } \\
\text { I will make money." }\end{array}$ \\
\hline
\end{tabular}


Table VI. Representative quotes for heuristic 4: Communicate a coherent narrative

\begin{tabular}{|c|c|}
\hline Quote & $\begin{array}{l}\text { Job of the interviewee, context of the quote, and } \\
\text { mapping to definition of heuristic }\end{array}$ \\
\hline $\begin{array}{l}\text { 1. "[The first] story predicts that by the end of [the year], } \\
\text { inflation is back to under } 2 \% \text {, the second story was that } \\
\text { inflation will be closer to } 3 \%,[\ldots] \text { the first story was that } \\
\text { the significant slack in labor market should put pay pressure } \\
\text { down and this should lead to low inflation. [the second } \\
\text { story was:] If you believe that inflation will be down to } \\
1.8 \% \text {, then you have to believe that other components in } \\
\text { the consumer basket will go down by unusual amounts." }\end{array}$ & $\begin{array}{l}\text { Senior economist in the structural economic analysis } \\
\text { division of the central bank, who does research on } \\
\text { modelling and forecasting and is a member of the } \\
\text { large staff that presents GDP and forecasts to the } \\
\text { monetary policy committee. If there is a } \\
\text { contradiction, central bankers appear to challenge } \\
\text { the structure of a corresponding narrative. }\end{array}$ \\
\hline $\begin{array}{l}\text { 2. "[The monetary policy committee] selects between } \\
\text { narratives. [...] There may be nine different views, [but the } \\
\text { committee] needs to compromise on a single probability } \\
\text { distribution." }\end{array}$ & $\begin{array}{l}\text { Member of the monetary policy committee at the } \\
\text { central bank, who describes the role of narratives in } \\
\text { finding a monetary policy decision. The quote } \\
\text { highlights the prominent role of narratives in } \\
\text { agreeing on monetary policy decisions and } \\
\text { predictions ("a single probability distribution") of } \\
\text { the central bank. }\end{array}$ \\
\hline $\begin{array}{l}\text { 3. "Weak productivity growth leads to loss in output-the } \\
\text { disagreement is whether this is temporary or permanent; } \\
\text { furthermore, there are different explanations for this output } \\
\text { loss. First: [that the] financial sector [is] now smaller; then } \\
\text { the output loss would be permanent; second: [that the] } \\
\text { number of people looking for work increases; then the } \\
\text { output loss would be temporary." }\end{array}$ & $\begin{array}{l}\text { The same, as in the row above, member of the } \\
\text { monetary policy committee in the central bank, } \\
\text { gives an example of two competing narratives. The } \\
\text { narratives contain aggregated actors ("the financial } \\
\text { sector", "people looking for work"), and a time } \\
\text { structure ("output loss would be } \\
\text { permanent/temporary"). }\end{array}$ \\
\hline $\begin{array}{l}\text { 4. "If me and another guy from [another major investment } \\
\text { bank] make competing recommendations (buy and sell), } \\
\text { then the equity traders on the phone repeat these } \\
\text { competing narratives." }\end{array}$ & $\begin{array}{l}\text { Equity research analyst at the investment bank. The } \\
\text { quote points to an example of the use of narratives } \\
\text { in this bank. To anticipate prices on a longer time } \\
\text { scale (analysts' recommendations and price targets } \\
\text { refer to time horizons of months to years, not days } \\
\text { or weeks), traders as well seem to use narratives. }\end{array}$ \\
\hline
\end{tabular}

